\title{
Anti-leukemic effect of sodium metaarsenite (KML001) in acute myeloid leukemia with breaking-down the resistance of cytosine arabinoside
}

\author{
JIN SUN YOON ${ }^{1}$, EUN SHIL KIM ${ }^{1}$, BYEONG BAE PARK ${ }^{1}$, JUNG HYE CHOI ${ }^{1}$, \\ YOUNG WOONG WON ${ }^{1}$, SUJONG KIM ${ }^{2}$ and YOUNG YIUL LEE ${ }^{1}$ \\ ${ }^{1}$ Department of Internal Medicine, Hanyang University College of Medicine, Seoul; \\ ${ }^{2}$ Pharmaceutical Division, Komipharm International Co., Ltd., Seoul, Republic of Korea
}

Received November 18, 2014; Accepted December 29, 2014

DOI: $10.3892 /$ ijo.2015.2899

\begin{abstract}
Sodium metaarsenite $\left(\mathrm{NaAs}_{2} \mathrm{O}_{3}\right.$ : code name KML001) is an orally bioavailable arsenic compound with potential anti-cancer activity. However, the effect of KML001 has not been studied in acute myeloid leukemia (AML). We investigated the anti-leukemic effect of KML001 in AML, and determined the mode of action of KML001. KML001 inhibited the cellular proliferation in all AML cell lines and primary AML blasts as well as HL-60R (cytosine arabinoside-resistant HL-60) cells, while $\mathrm{As}_{2} \mathrm{O}_{3}$ was not effective in primary AML blasts and AML cell lines including HL-60R cells. KML001 induced G1 arrest and apoptosis in HL-60 and HL-60R cells. KML001 inhibited the activation of STAT (signal transducer and activator of transcription) $1,3,5, \mathrm{NF}-\kappa \mathrm{B}, \mathrm{AKT}$ and PI3K, while phosphorylated PTEN was upregulated. In addition, activation of ERK, p38 and JNK was observed in KML001induced growth inhibition of HL-60 and HL-60R cells. Furthermore, KML001 induced telomeric terminal restriction fragment (TRF) length shortening in a time-dependent manner in HL-60 and HL-60R cells. Real-time PCR with RNA extracted from KML001-treated HL-60 and HL-60R cells showed a significant reduction of catalytic subunit of telomerase, hTERT, in a time-dependent manner. Additionally, $\gamma-\mathrm{H}_{2} \mathrm{~A}_{\mathrm{X}}$, a sensitive molecular marker of DNA damage, in HL-60 and HL-60R cells was induced by KML001. These results suggest that KML001 inhibits the proliferation of AML cells including cytosine arabinoside-resistant AML cells via various mechanisms such as cell cycle arrest, induction of apoptosis, inhibition of JAK/STAT and PI3K pathways, activation of MAPK pathway and telomere targeting.
\end{abstract}

Correspondence to: Professor Young Yiul Lee, Division of Hematology/Oncology, Department of Internal Medicine, Hanyang University Hospital, 17 Haeng Dang-dong, Sung Dong-ku, Seoul 133-792, Republic of Korea

E-mail: leeyy@hanyang.ac.kr

Key words: acute myeloid leukemia, sodium metaarsenite, antileukemic effect, telomere, cell signaling

\section{Introduction}

Arsenic compounds have been used in traditional medicine as anti-tumor and anti-inflammatory agents over 2,400 years, however, their clinical use is strikingly decreased because of the carcinogenic and toxic effects (1). Since successful use of arsenic trioxide (ATO; $\mathrm{As}_{2} \mathrm{O}_{3}$ ) in patients with acute promyelocytic leukemia (APL) in China in the 1970s, ATO was approved for clinical use for patients with relapsed APL $(2,3)$. Also, in vitro studies have shown that ATO exerts anti-proliferative effect on solid tumor cells including prostate, ovarian, stomach, breast, lung and cervical cancer (4-6). The anti-tumoral effect of ATO is accompanied by tubulin polymerization, induction of differentiation and apoptosis and inhibition of angiogenesis (4,6-8). Arsenic compounds have also been reported to target telomere which is a region of repetitive nucleotide sequences at each end of a chromatid and protects the end of the chromosome from deterioration or from fusion with neighbouring chromosomes (9). Arsenic-induced inhibition of human telomerase reverse transcriptase (hTERT) is associated with transcriptional factors, c-Myc and Sp1 (10). However, the anti-tumor effect of ATO in solid tumors and other hematologic disorders has not been fully elucidated (11). Especially, a drawback of ATO is to be administered intravenously, and not effective in the treatment of acute myeloid leukemia (AML) except one type called APL.

KML001, sodium metaarsenite, is a water-soluble, therefore, orally bioavailable, trivalent arsenical compound (12). KML001 has shown potent anti-tumoral effect in vitro as well as in human solid tumor cell line xenografts in vivo, and has entered phase $1 / 2$ clinical trials for the treatment of human prostate cancer $(12,13)$. It has been suggested that one of the mechanisms of action of KML001 might be to target the telomeres of chromosomes in cancer cells (12). Although KML001 has shown cytotoxic effect on a variety of cancer cells, antileukemic effect of KML001 has not been well studied yet.

In the present study, we investigated the effect of KML001 on acute myeloid leukemia (AML) cell lines. KML001 inhibited the proliferation of all AML cell lines including Ara-C (cytosine arabinoside)-resistant HL-60 (HL-60R) cells by cell cycle arrest and induction of apoptosis. In addition, KML001 
shortened the telomere length without affecting telomerase activity. All together, KML001 seems to be a candidate agent for clinical investigation in the treatment of refractory acute myeloid leukemia.

\section{Materials and methods}

Cells and cell culture. Human myeloid leukemia cell lines examined in the present study were HL-60, BV173, HEL, K562, KCL22, KG1, KU812, MegO1, ML1, NB4 and U937, and they were kindly presented by Dr H.P. Koeffler (Cedars-Sinai Medical Center/University of California, Los Angeles, CA, USA). The cells were cultured in tissue flasks in RPMI-1640 medium (Gibco-BRL, Gaithersburg, MD, USA) supplemented with $10 \%$ (vol/vol) fetal bovine serum (FBS; Gibco-BRL), $100 \mathrm{U} / \mathrm{ml}$ penicillin and $100 \mu \mathrm{g} / \mathrm{ml}$ streptomycin (Sigma Chemical, St. Louis, MO, USA) and maintained in a humidified atmosphere, $5 \% \mathrm{CO}_{2}$ at $37^{\circ} \mathrm{C}$. The culture medium was changed every 3-4 days. The Ara-C-resistant cell line HL-60R was established by stepwise increase of concentrations of cytosine arabidoside in medium. Leukemic blasts were harvested from bone marrow aspirates of $4 \mathrm{AML}$ patients (2 AML M1 and 2 AML M2), who were initially diagnosed when the blasts counts were high $(>85 \%)$ at presentation and gave written informed consent. Mononuclear cells (MNCs) from bone marrow were collected by separation on Ficoll-Paque (Amersham Biosciences AB, Uppsala, Sweden) gradients at a density of 1.077, washed twice in phosphate-buffered saline (PBS), and suspended in Iscove's modified Dulbecco's medium (IMDM; Gibco-BRL) containing 10\% heat-inactivated FBS (Gibco-BRL).

Reagents. KML001 (sodium metaarsenite) was obtained from Komipharm International, $10^{-3} \mathrm{M}$ drug stocks were prepared in distilled water and aliquots were stored at $4^{\circ} \mathrm{C}$. The stock solution was stable for $>1$ year. Working concentrations were freshly prepared daily by diluting the stock with RPMI-1640. $\mathrm{As}_{2} \mathrm{O}_{3}$ was purchased from Sigma-Aldrich, $5 \times 10^{-2} \mathrm{M}$ stock solution was prepared in $5 \mathrm{M} \mathrm{NaOH}$, and aliquots were stored at $4^{\circ}$ C. SP600125, a specific JNK inhibitor, and SB202190, specific inhibitor of $\mathrm{p} 38$ protein were purchased from Calbiochem (San Diego, CA, USA) (14). These inhibitors were dissolved in dimethyl sulfoxide (DMSO) at $1 \mathrm{mM}$ as stock solutions and these stock solutions were stored at $-20^{\circ} \mathrm{C}$.

Growth inhibition assay. Cellular growth inhibition effect of KML001 was determined by measuring the MTT [3[4,5-dimethylthiazol-2-yl]-2,5-diphenyltetrazolium bromide dye absorbance of living cells as previously described (15). Briefly, cells $\left(1 \times 10^{4}\right.$ cells/well) were seeded in 96-well microtiter plates (Nunc, Roskilde, Denmark) and incubated at $37^{\circ} \mathrm{C}$ for $72 \mathrm{~h}$. MTT solution $(50 \mu \mathrm{l})(2 \mu \mathrm{g} / \mathrm{ml}$ in PBS) from Sigma was added to each well, and the plates were incubated for an additional $4 \mathrm{~h}$ at $37^{\circ} \mathrm{C}$. The MTT solution in the medium was aspirated. To achieve solubilization of the formazan crystal formed in viable cells, $200 \mu \mathrm{l}$ of DMSO was added to each well. The plates were shaken for $30 \mathrm{~min}$ at room temperature, and absorbance was read immediately at a wavelength of $540 \mathrm{~nm}$ on a scanning multiwell spectrophotometer (Titert Multiscan MC; Flow Laboratory, CA).
Cell cycle analysis. Cells were fixed with methanol for $1 \mathrm{~h}$ and stained with $50 \mu \mathrm{g} / \mathrm{ml}$ of propidium iodide (PI) containing $50 \mu \mathrm{g} / \mathrm{ml}$ of RNaseA. The DNA contents of the cells $(10,000$ cells/experimental group) were analyzed using a FACStar flow cytometer (Becton-Dickinson, San Jose, CA, USA) equipped with a ModFit LT program (Lysis II, CellFit). The percentage of cell population in each cell cycle phase $(\mathrm{G} 1, \mathrm{~S}$ or $\mathrm{G} 2 / \mathrm{M})$ was calculated from DNA content histograms, excluding the population in the sub-G1 phase.

Evaluation of apoptosis. Apoptosis was determined by staining cells with Annexin V-FITC (BD Biosciences, San Diego, CA, USA) and PI (16). To quantify the apoptosis of cells, the cells were washed twice with cold PBS and were resuspended in binding buffer (10 mM HEPES/NaOH, pH 7.4, $140 \mathrm{mM} \mathrm{NaCl}$, $\left.2.5 \mathrm{mM} \mathrm{CaCl}_{2}\right)$ at a density of $1 \times 10^{6}$ cells $/ \mathrm{ml}$. This cell solution $(100 \mu \mathrm{l})$ (total $1 \times 10^{5}$ cells) was transferred to a $5-\mathrm{ml}$ culture tube with $5 \mu \mathrm{l}$ of Annexin V-FITC and $10 \mu \mathrm{l}$ of PI $(20 \mu \mathrm{g} / \mathrm{ml})$ and was analyzed with the FACStar flow cytometer.

Immunoblot analysis. Cells were suspended in lysis buffer containing $50 \mathrm{mM}$ Tris (pH 7.5), 1\% NP-40, 2 mM EDTA, $10 \mathrm{mM} \mathrm{NaCl}, 20 \mu \mathrm{g} / \mathrm{ml}$ aprotinin, $20 \mu \mathrm{g} / \mathrm{ml}$ leupeptin and $1 \mathrm{mM}$ phenylmethylsulphonyl fluoride and were placed on ice for $20 \mathrm{~min}$. Samples containing $20-100 \mu \mathrm{g}$ of total protein were resolved in SDS-polyacrylamide denaturing gel, transferred to nitrocellulose membranes, and probed with antibodies. The blots were developed using the ECL kit (Intron Biotechnology, Gyeonggi-do, Korea).

Immunoprecipitation and kinase assay. Cells were suspended in an extraction buffer [50 mM Tris- $\mathrm{Cl}(\mathrm{pH} 7.5), 250 \mathrm{mM}$ $\mathrm{NaCl}, 0.1 \%$ NP-40, 5 mM EDTA, $50 \mathrm{mM} \mathrm{NaF}, 0.1 \mathrm{mM} \mathrm{NaVO}_{4}$, $100 \mathrm{mM}$ phenylmethylsulfonyl fluoride, $0.2 \mathrm{mM}$ leupeptin, $10 \mu \mathrm{g} / \mathrm{ml}$ aprotinin, $0.1 \mathrm{mM}$ pepstatin A) and incubated on ice for $15 \mathrm{~min}$. After centrifugation at $13,000 \mathrm{rpm}$ for $20 \mathrm{~min}$, the supernatant was collected and protein concentration was determined using a Bio-Rad assay kit. Two micrograms of each antibody (CDK2, CDK4 and CDK6) were added to $200 \mu \mathrm{g}$ of each cell extract in $500 \mu \mathrm{l}$ of extraction buffer and incubated for $4 \mathrm{~h}$ at $4{ }^{\circ} \mathrm{C}$ with continuous agitation. To collect immune complexes, $30 \mu \mathrm{l}$ of protein $\mathrm{A} / \mathrm{G}$-agarose was added to the mixture, which was then incubated for $2 \mathrm{~h}$. Immune complexes were centrifuged at 1,200 rpm for $2 \mathrm{~min}$ and the precipitates were washed three times with extraction buffer and twice with kinase reaction buffer [50 $\mathrm{mM}$ Tris-Cl (pH 7.5), $10 \mathrm{mM} \mathrm{MgCl}_{2}$ and $1 \mathrm{mM}$ DTT]. CDK 2 kinase assays on histone $\mathrm{H} 1$ was performed by mixing the respective immune complexes with $5 \mu \mathrm{g}$ of histone $\mathrm{H} 1$ and $1 \mu \mathrm{Ci}$ of $\left[\gamma^{-}{ }^{32} \mathrm{P}\right]-\mathrm{ATP}$ in $35 \mu \mathrm{l}$ of kinase reaction buffer. CDK 4 and $\mathrm{CDK} 6$ kinase assays on $\mathrm{Rb}-\mathrm{c}$ residue were performed in the same way. Kinase reactions were performed at $37^{\circ} \mathrm{C}$ for $30 \mathrm{~min}$ and were terminated with $2 \mathrm{X}$ SDS-PAGE loading buffer. The reaction mixtures were resolved by SDS-PAGE. The extent of phosphorylation was determined by autoradiography.

Mean telomere restriction fragment length. For the measurement of telomere length, Roche Diagnostics TeloTAGG telomere restriction fragment (TRF) length kit was used 
according to manufacturer's instructions (Roche Diagnostics $\mathrm{GmbH}$, Mannheim, Germany).

Quantitative hTERT real-time PCR. Total RNA was isolated with TRI reagent (Molecular Research Center, Inc., Cincinnati, $\mathrm{OH}, \mathrm{USA}$ ) and cDNA was synthesized from $1 \mu \mathrm{g}$ of total RNA using ImProm-II Reverse Transcriptase (Promega Corp., Madison, WI, USA) and random hexamers. Quantitative PCR was performed using SYBR-Green I as a double-strand DNA-specific binding dye on iCycler IQ detection system (BioRad Laboratories). Thermocycling was performed in a final volume of $20 \mu \mathrm{l}$ containing; $4 \mu \mathrm{l}$ cDNA sample, $10 \mathrm{pM}$ of each primer, $0.125 \mathrm{mM}$ dNTP mixture, $0.25 \mathrm{mg} / \mathrm{ml} \mathrm{BSA}, 0.05 \%$ Tween-20, $1 \mathrm{X}$ rTaq reaction buffer containing $1.5 \mathrm{mM} \mathrm{MgCl} \mathrm{m}_{2}$ (Takara, Shiga, Japan), 1 unit rTaq DNA polymerase (Takara), and 1X SYBR-Green I (Molecular Probes, Sunnyvale, CA, USA). After an initial denaturation at $95^{\circ} \mathrm{C}$ for $10 \mathrm{~min}, 35$ cycles of $94^{\circ} \mathrm{C}$ for $30 \mathrm{sec}, 53^{\circ} \mathrm{C}$ for $30 \mathrm{sec}$, and $72^{\circ} \mathrm{C}$ for $30 \mathrm{sec}$ were carried out.

All cDNA samples were synthesized in parallel and PCR reactions were run in triplicate. The mRNA levels were derived from standard curves and are expressed as relative changes after normalization vs. $\beta$-actin mRNA levels.

Chromatin immunoprecipitation (ChIP). HL-60 and HL-60R cells were treated with KML001 at a concentration of $10^{-7} \mathrm{M}$ for 24, 48 and $72 \mathrm{~h}$. Chromatin immunoprecipitation (ChIP) assays for studying the specific association of $\gamma-\mathrm{H}_{2} \mathrm{~A}_{X}$ with telomeric repeat sequences were performed as described by d'Adda di Fagagna et al (17). Briefly, cells were fixed in 1\% formaldehyde in PBS for $10 \mathrm{~min}$ at $37^{\circ} \mathrm{C}$ and lysed with cell lysis buffer [1\% SDS, $50 \mathrm{mM} / 1$ Tris- $\mathrm{HCl}(\mathrm{pH} 8.0)$ and $10 \mathrm{mM} / 1$ EDTA] at a density of $10^{7}$ cells $/ \mathrm{ml}$. Lysates were sonicated to shear the DNA and centrifuged for $10 \mathrm{~min}$ at $4^{\circ} \mathrm{C}$. Lysates $(200 \mu \mathrm{l})$ were diluted with a buffer $[1.8 \mathrm{ml}$ of $0.01 \%$ SDS, 1.1\% Triton X-100, $1.2 \mathrm{mmol} / 1$ EDTA, $16.7 \mathrm{mmol} / 1$ Tris-HCl (pH 8.0) and $150 \mathrm{mmol} / \mathrm{l} \mathrm{NaCl}]$ and precleaned with a protein $\mathrm{G}$ plus/protein A agarose suspension (Calbiochem, San Diego, CA, USA)/salmon sperm DNA (Invitrogen, Carlsbad, CA, USA). Control IgG (mouse; Santa Cruz Biotechnology, Santa Cruz, CA, USA), mouse monoclonal anti-phospho- $\mathrm{H}_{2} \mathrm{~A}_{\mathrm{X}}$ (EMD Millipore, Darmstadt, Germany; clone JBW301), or antitelomere repeat biding factor 1 antibodies (clone C-19; Santa Cruz Biotechnology) were added to the lysates and incubated overnight at $4^{\circ} \mathrm{C}$. Immunoprecipitated pellets were washed with $0.1 \%$ SDS, $1 \%$ Triton X-100, 2 mmol/1 EDTA (pH 8.0) and $20 \mathrm{mmol} / \mathrm{l}$ Tris- $\mathrm{HCl}(\mathrm{pH} 8.0)$ containing $150 \mathrm{mmol} / \mathrm{l} \mathrm{NaCl}$ in the first wash and $500 \mathrm{mmol} / 1 \mathrm{NaCl}$ in the second wash. Further washes were with $0.25 \mathrm{~mol} / 1 \mathrm{LiCl}, 1 \% \mathrm{NP}-40,1 \%$ sodium deoxycholate, $1 \mathrm{mmol} / \mathrm{l}$ EDTA (pH 8.0) and $10 \mathrm{mmol} / \mathrm{l}$ Tris- $\mathrm{HCl}(\mathrm{pH} \mathrm{8.0)}$ and with $10 \mathrm{mmol} / \mathrm{l}$ Tris- $\mathrm{HCl}(\mathrm{pH} 8.0)$ and $1 \mathrm{mmol} / \mathrm{l}$ EDTA. Chromatin was eluted from the beads with $500 \mu \mathrm{l}$ of $1 \% \mathrm{SDS}$ and $0.1 \mathrm{~mol} / 1 \mathrm{NaHCO}_{3}$. After addition of $20 \mu \mathrm{l}$ of $5 \mathrm{~mol} / \mathrm{l} \mathrm{NaCl}$, cross-links were reversed for $4 \mathrm{~h}$ at $65^{\circ} \mathrm{C}$. Samples were then treated with $20 \mu \mathrm{l}$ of $1 \mathrm{~mol} / 1 \mathrm{Tris}-\mathrm{HCl}$ (pH 6.5), $10 \mu \mathrm{l}$ of $0.5 \mathrm{~mol} / 1$ EDTA and $20 \mu \mathrm{g}$ Proteinase $\mathrm{K}$ (Invitrogen) and incubated at $45^{\circ} \mathrm{C}$ for $1 \mathrm{~h}$. Phenol-chloroform extractions were done and the DNA was precipitated overnight at $-80^{\circ} \mathrm{C}$. The precipitate was dissolved in $20 \mu \mathrm{l}$ water just prior to setting up qPCR runs (18).
Table I. Cell cycle analysis in KML001-treated HL-60.

\begin{tabular}{lcccccc}
\hline & $0 \mathrm{~h}$ & $12 \mathrm{~h}$ & $18 \mathrm{~h}$ & $24 \mathrm{~h}$ & $48 \mathrm{~h}$ & $72 \mathrm{~h}$ \\
\hline G0-G1 & 46.21 & 48.02 & 41.61 & 42.33 & N.D & 64.56 \\
S & 40.48 & 38.76 & 29.05 & 34.52 & N.D & 23.77 \\
G2/M & 12.31 & 13.22 & 29.33 & 21.15 & N.D & 11.67 \\
SubG1 & 2.10 & 11.22 & 70.79 & 51.30 & 74.58 & 48.04 \\
Debris & 2.04 & 11.33 & 90.77 & 66.07 & N.D & 50.36 \\
\hline
\end{tabular}

N.D, not detected.

Table II. Cell cycle analysis in KML001-treated HL-60R.

\begin{tabular}{lrrrrrr}
\hline & $0 \mathrm{~h}$ & $12 \mathrm{~h}$ & $18 \mathrm{~h}$ & $24 \mathrm{~h}$ & $48 \mathrm{~h}$ & $72 \mathrm{~h}$ \\
\hline G0-G1 & 28.28 & 36.34 & 50.90 & 35.13 & N.D & 59.67 \\
S & 56.11 & 46.13 & 38.48 & 18.96 & N.D & 36.95 \\
G2/M & 15.07 & 17.53 & 10.62 & 15.90 & N.D & 3.37 \\
SubG1 & 3.99 & 21.81 & 11.13 & 3.08 & 63.71 & 57.86 \\
Debris & 6.27 & 21.59 & 11.89 & 4.37 & N.D & 66.34 \\
\hline
\end{tabular}

N.D, not detected.

Statistical analysis. The data represent mean values \pm SEM (error bars) of experiments repeated at least 3 times. Statistical significance was determined using the Student's t-tests. P-values $<0.05$ were considered statistically significant.

\section{Results}

Antileukemic effect of KML001 on human leukemic cells. KML001 inhibited the cellular proliferation in all AML cell lines in a dose-dependent manner with $\mathrm{IC}_{50}$ of $5 \times 10^{-8} \mathrm{M}$, while arsenic trioxide $\left(\mathrm{As}_{2} \mathrm{O}_{3}\right)$ did not (Fig. 1A and B). KML001 effectively inhibited cellular proliferation of HL-60 cells $\left(\mathrm{IC}_{50} ; 5 \times 10^{-8} \mathrm{M}\right)$ as well as HL-60R cells $\left(\mathrm{IC}_{50} ; 1 \times 10^{-8} \mathrm{M}\right)$, and its anti-leukemic effect was almost the same as Ara-C $\left(\mathrm{IC}_{50} ; 5 \times 10^{-8} \mathrm{M}\right)$. Ara-C did not inhibit cellular proliferation in HL-60R cells as expected (Fig. 1C and D). In addition, growth of primary leukemic blasts from AML patients was inhibited in a dose-dependent manner by $\mathrm{KML} 001$ with $\mathrm{IC}_{50}$ of $5 \times 10^{-7} \mathrm{M}$, however, arsenic trioxide did not inhibit the primary leukemic blast cells (Fig. 1E and F). These data indicated that KML001 might be a potent anti-leukemic agent, and have biological effects different from arsenic trioxide on AML cells including Ara-C-resistant HL-60 cells.

Cell cycle analysis in HL-60 and HL-60R cells. The effect of KML001 on the cell cycle was determined in HL-60 and HL-60R cells by FACS analysis. Three independently performed DNA flow cytometric analyses indicated that KML001 induced a G1 arrest in HL-60 and HL-60R cells at a concentration of $1 \times 10^{-7} \mathrm{M}$ during $72 \mathrm{~h}$ of exposure; population of HL-60 cells in G1 phase was $46.21 \%$ at $0 \mathrm{~h}$ and $64.56 \%$ at $72 \mathrm{~h}$ (Table I). Population of HL-60R cells was $28.82 \%$ at $0 \mathrm{~h}$ and $59.67 \%$ at $72 \mathrm{~h}$ (Table II). In contrast, no cell cycle 
A Leukemia Cell Line (Kominox)
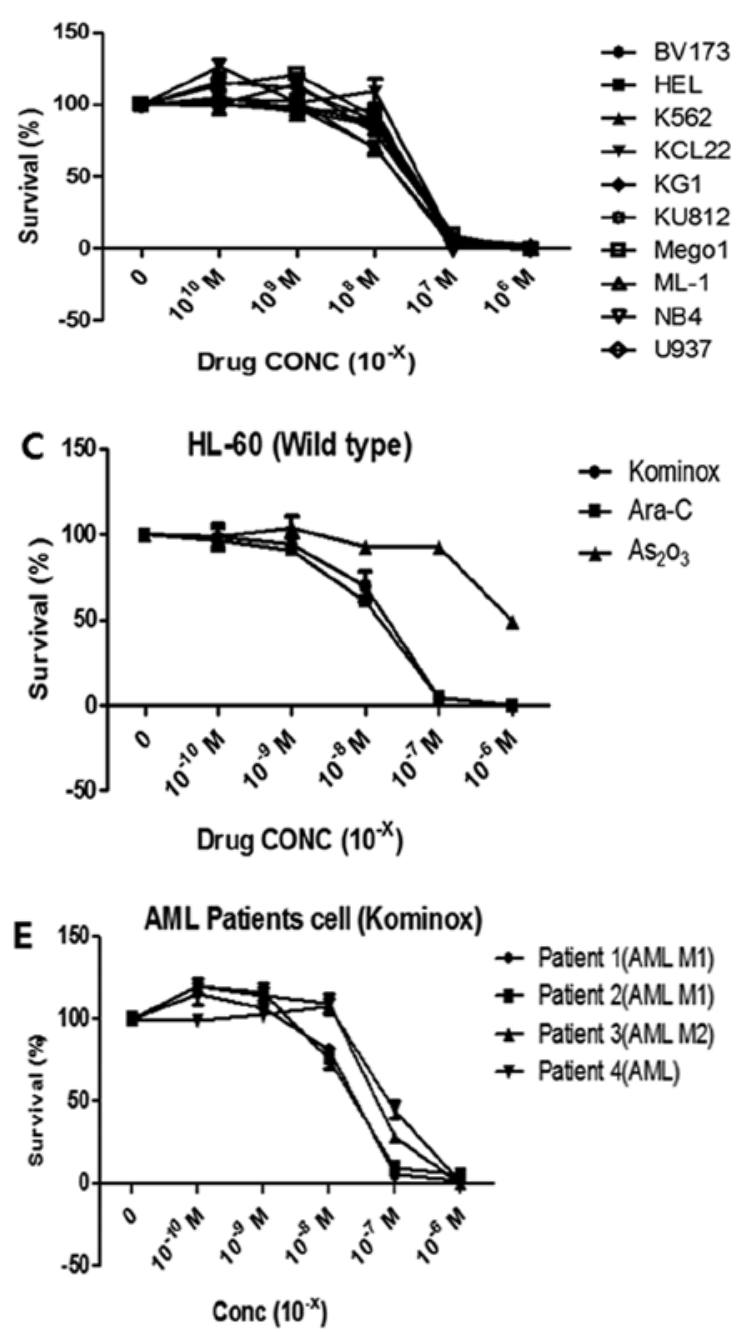
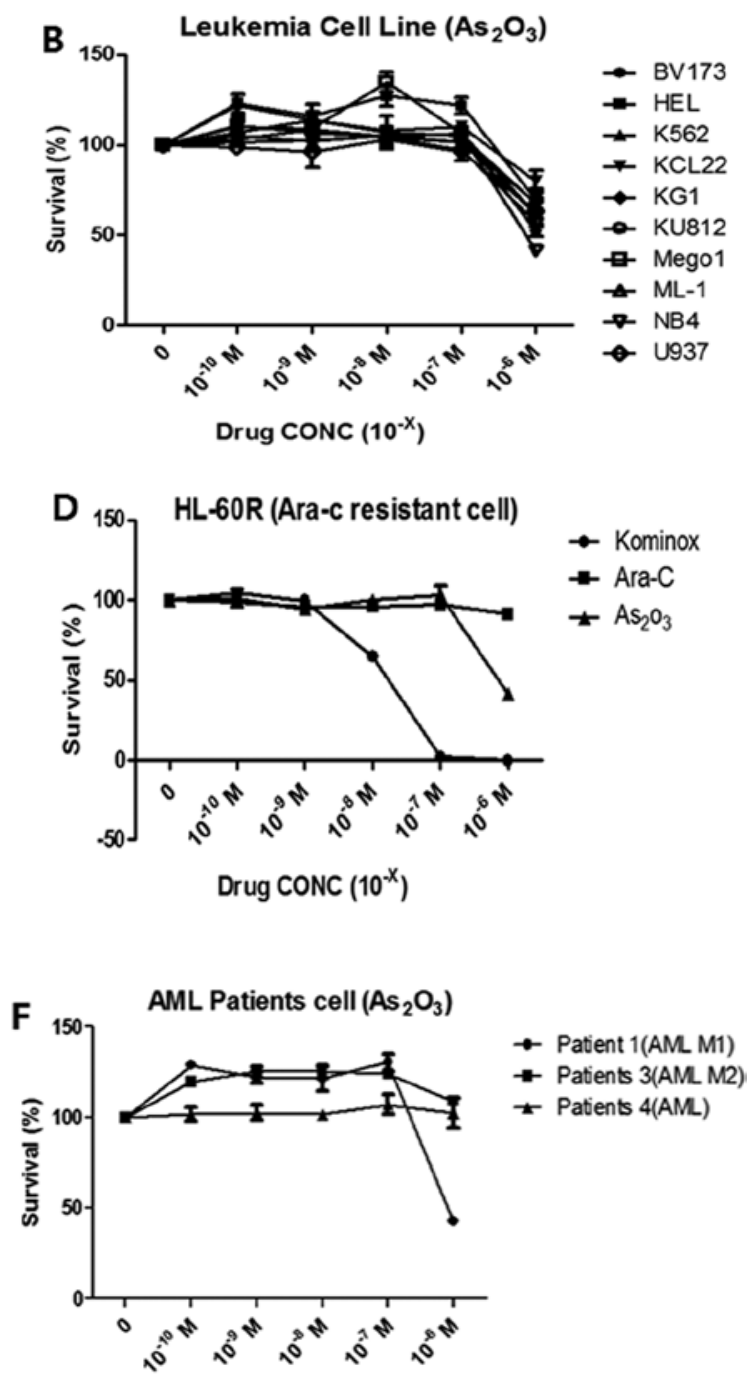

Figure 1. Effect of KML001 and $\mathrm{As}_{2} \mathrm{O}_{3}$ on cellular proliferation. (A) Effect of KML001 in AML cell lines. Cellular proliferation of AML cell lines was determined by MTT assay after treatment of KML001 for $72 \mathrm{~h}$. (B) Effect of $\mathrm{As}_{2} \mathrm{O}_{3}$ in AML cell lines. Cellular proliferation of AML cell lines was determined by MTT assay after treatment of $\mathrm{As}_{2} \mathrm{O}_{3}$ for 72 h. (C) Effect of KML001, Ara-C and $\mathrm{As}_{2} \mathrm{O}_{3}$ on HL-60 cells. Proliferation of HL-60 cells was determined by MTT assay after treatment of agents for 72 h. (D) Effect of KML001, Ara-C and $\mathrm{As}_{2} \mathrm{O}_{3}$ on HL-60R cells. Proliferation of HL-60R cells was determined by MTT assay after treatment of agents for $72 \mathrm{~h}$. (E) Effect of KML001 on AML blasts isolated from AML patients. Cellular proliferation of AML blasts was determined by MTT assay after treatment of KML001 for $72 \mathrm{~h}$. (F) Effect of $\mathrm{As}_{2} \mathrm{O}_{3}$ on AML blasts isolated from AML patients. Cellular proliferation of AML blasts was determined by MTT assay after treatment of $\mathrm{As}_{2} \mathrm{O}_{3}$ for $72 \mathrm{~h}$.

arrest was observed in HL-60 and HL-60R cells with $\mathrm{As}_{2} \mathrm{O}_{3}$ treatment (data not shown).

Cell cycle arrest was associated with downregulation of CDKs of CDK4, CDK6, as well as cyclins of cyclin D1 and cyclin E. In addition, the expression of p21 and p27 proteins, and cyclin-dependent kinase inhibitors (CDKIs), was increased in HL-60 and HL-60R cells. In contrast, no significant change of CDKs and cyclins was observed and the expression of CDKIs was decreased in arsenic trioxide-treated HL-60 and HL-60R cells (Fig. 2A).

Association of p27 with cell cycle-regulatory proteins in KML001-treated HL-60 and HL-60R cells. Since western blot analysis showed that KML001 induced a marked accumulation of p27 protein, we investigated whether the KML001-induced p27 protein existed in complexes with CDKs active in the G1 phase of the cell cycle in HL-60 and HL-60R cells. As shown in Fig. 2B, the complexes immunoprecipitated with
anti-CDK2, anti-CDK4 and anti-CDK6 antibodies exhibited higher levels of immunodetectable p27 protein in HL-60 and HL-60R cells at $72 \mathrm{~h}$.

Effect of KML001 on CDK-associated kinase activity. To determine whether the increased CDKIs and the changed cell cycle-regulatory proteins result in the inhibition of CDK activity in KML001-treated HL-60 and HL-60R cells, in vitro CDK activity assay on $\mathrm{Rb}-\mathrm{c}$ substrate and histone $\mathrm{H} 1$ was performed using immunoprecipitation with anti-CDK2, antiCDK4 and anti-CDK6 antibodies. HL-60 and HL-60R cells treated with KML001 at a concentration of $1 \times 10^{-7} \mathrm{M}$ showed a decrease in CDK2-associated kinase activity on histone $\mathrm{H} 1$, and CDK4- and CDK6-associated kinase activity on Rb-c substrate at $72 \mathrm{~h}$ (Fig. 2C).

Taken together, these results suggest that $\mathrm{p} 27$ protein could play a critical role in a G1 arrest via its increased binding to CDK2, CDK4 and CDK6 proteins and subsequent inhibition 


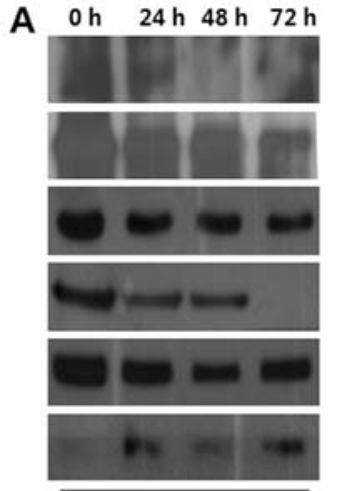

HL-60 KML001 $10^{-7} \mathrm{M}$

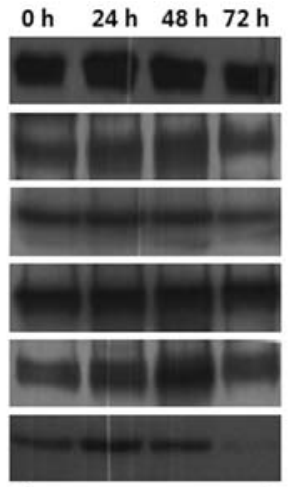

$\mathrm{HL}-60 \mathrm{AS}_{2} \mathrm{O}_{3} \quad 10^{-7} \mathrm{M}$

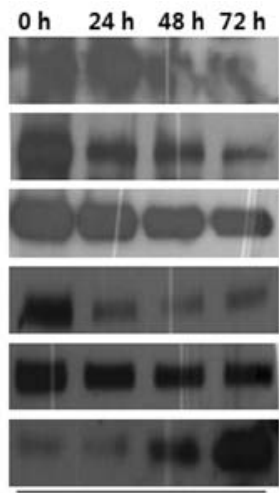

HL-60R KML001 $10^{-7} \mathrm{M}$

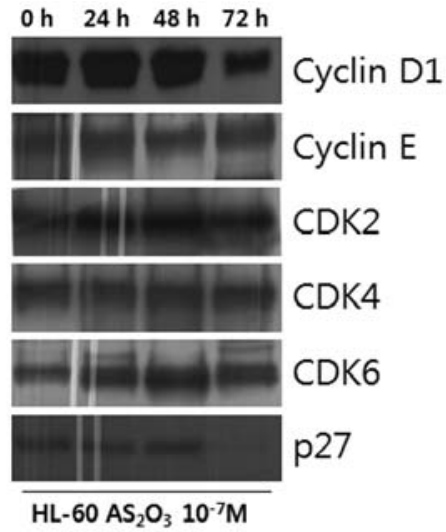

B $\mathrm{Oh}$

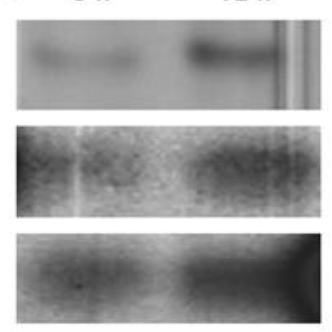

HL-60 KML001

\section{CDK2 + p27}

CDK4 + p27

\section{$\mathrm{Oh}$}

$72 \mathrm{~h}$

\section{CDK6 + p27}
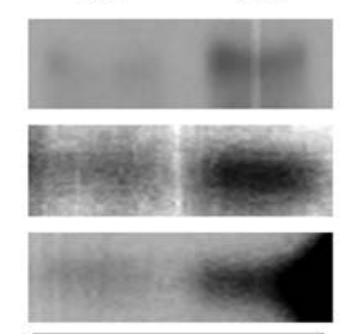

HL-60R KML001
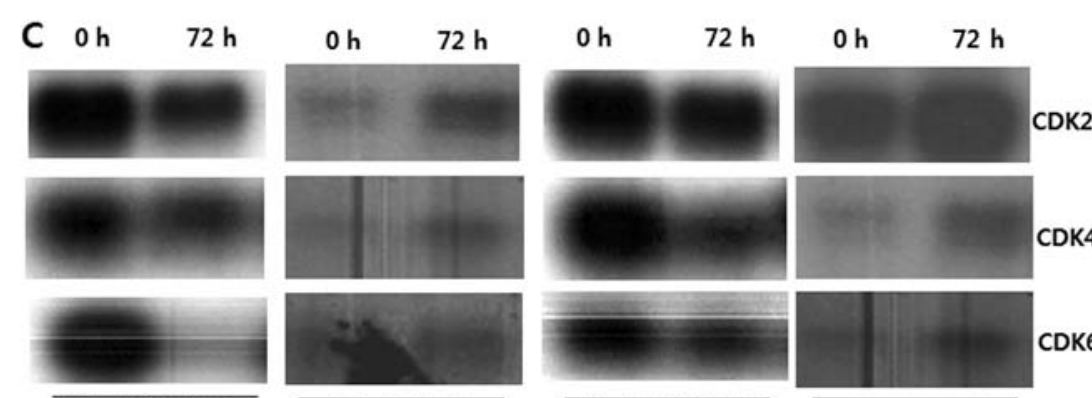

HL-60R KML001

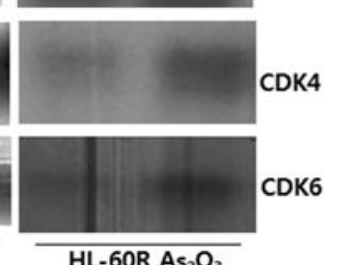

Figure 2. Effect of KML001 and $\mathrm{As}_{2} \mathrm{O}_{3}$ on cell cycle. (A) Modulation of cell cycle-regulatory proteins in HL-60 and HL-60R. Cells were harvested at the indicated times after incubation with KML001 $\left(10^{-7} \mathrm{M}\right)$ or $\mathrm{As}_{2} \mathrm{O}_{3}\left(10^{-7} \mathrm{M}\right)$. Cells were then lysed, and the supernatants were subjected to western blot analysis. (B) Association of p27 with CDKs in HL-60 and HL-60R cells. Cells were treated with KML001 $\left(10^{-7} \mathrm{M}\right)$ for $72 \mathrm{~h}$. Total lysates were immunoprecipitated with anti-CDK2, anti-CDK4 and anti-CDK6 antibodies. The bound p27 in each immunocomplex was determined by western blot analysis. (C) Effect of KML001 and $\mathrm{As}_{2} \mathrm{O}_{3}$ on CDK-associated kinase activities in HL-60 and HL-60R cells. Cells were treated with KML001 $\left(10^{-7} \mathrm{M}\right)$ or As $\mathrm{O}_{3}\left(10^{-7} \mathrm{M}\right)$ for $72 \mathrm{~h}$. CDK activity assays on substrates were performed using immunoprecipitation with indicated antibodies.

of CDK2-, CDK4-, CDK6-associated kinase activities in KML001-treated HL-60 and HL-60R cells.

In contrast, arsenic trioxide did not reduce the activity of CDK2-, CDK4- and CDK6-associated kinase in HL-60 and HL-60R cells (Fig. 2C).

Induction of apoptosis by KML001 in HL-60 and HL-60R cells. In order to determine whether KML001 treatment could induce apoptosis in HL-60 and HL-60R cells, in vitro apoptosis detection assay was performed. Cells were stained with Annexin V-FITC and propidium iodide (PI) and analyzed by FACS. The proportion of Annexin V-FITC-stained cells was dramatically increased in a time-dependent manner following treatment of HL-60 and HL-60R cells with KML001 at a concentration of $1 \times 10^{-7} \mathrm{M}$ (Fig. 3A). In addition, Bcl-2 protein was downregulated in a dose-dependent manner in HL-60 and HL-60R cells (Fig. 3B). Next, it was evaluated whether caspase might be activated during the induction of apoptosis by
KML001, since cell death can be completed through caspase activation after external stimuli. The expression of effector caspase-3 was downregulated in a dose-dependent manner (Fig. 3B). Collectively, these results indicate that induction of apoptosis could be another mechanism of the antiproliferative effect of KML001 besides cell cycle arrest in HL-60 and HL-60R cells.

Effect of KML001 on cell signaling in HL-60 and HL-60R cells. STATs are cytoplasmic transcription factors and key mediators of cytokine and growth factor signaling pathways. Many malignant cells have shown to consistently express STAT molecules. In order to investigate the role of STAT molecules in anti-leukemic effect of KML001, HL-60 and HL-60R cells were treated with KML001 for $2 \mathrm{~h}$ at indicated concentrations.

The expression of p-STAT1, p-STAT3 and p-STAT5 was downregulated in HL-60 and HL-60R cells following treat- 
A

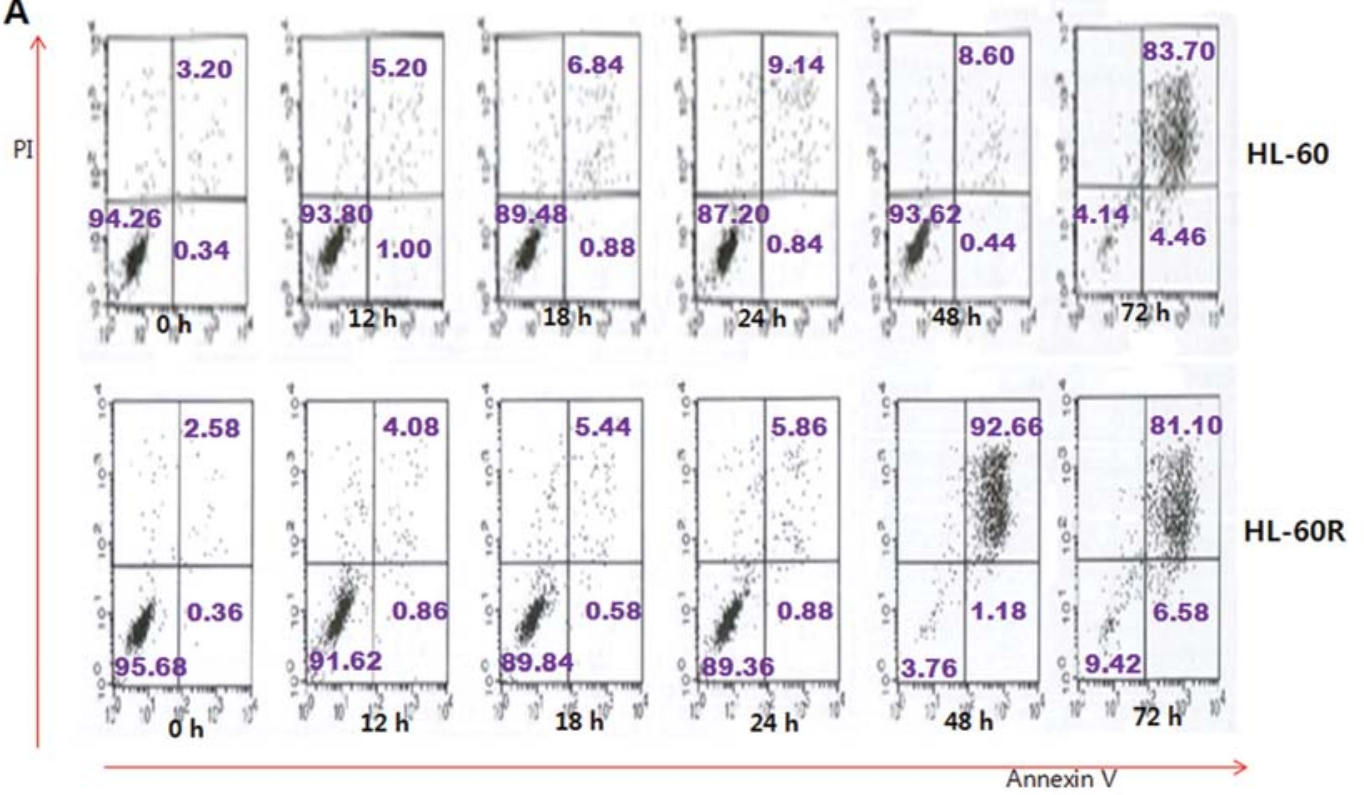

B CTR $10^{-5} \mathrm{M} 10^{-7} \mathrm{M} 10^{-6} \mathrm{M}$ CTR $10^{-5} \mathrm{M} 10^{-7} \mathrm{M} 10^{-5} \mathrm{M}$ CTR $10^{-5} \mathrm{M} 10^{-7} \mathrm{M} 10^{-5} \mathrm{M}$ CTR $10^{-5} \mathrm{M} 10^{-7} \mathrm{M} 10^{-5} \mathrm{M}$

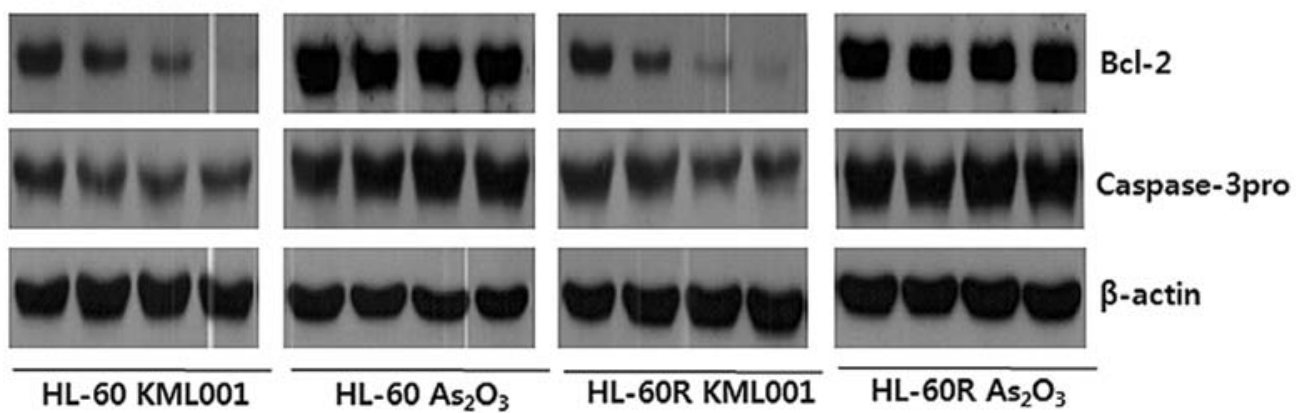

Figure 3. Effect of KML001 and $\mathrm{As}_{2} \mathrm{O}_{3}$ on apoptosis. (A) Induction of apoptosis by KML001 in HL-60 and HL-60R cells. Cells were stained with Annexin V-FITC and PI and analyzed by FACS. (B) Modulation of apoptosis-related proteins in HL-60 and HL-60R cells. Cells were treated with KML001 or $\mathrm{As}_{2} \mathrm{O}_{3}$ at indicated doses for $72 \mathrm{~h}$. Total protein was resolved in SDS-polyacrylamide denaturing gel, transferred to nitrocellulose membranes, and probed with indicated antibodies.

ment with KML001, while no significant expressional change was noted in $\mathrm{As}_{2} \mathrm{O}_{3}$-treated HL-60 and HL-60R cells (Fig. 4A). Regarding the MAPK signaling, the phosphorylated forms of p42/p44 ERK, JNK and p38 were increased following treatment of HL-60 and HL60-R cells with KML001 for $2 \mathrm{~h}$ in a dose-dependent manner, while no dramatic expressional change was shown in $\mathrm{As}_{2} \mathrm{O}_{3}$-treated cells, suggesting that the KML001-induced activation of MAPK pathways might be related to the growth inhibition of HL-60 and HL-60R cells (Fig. 4B). Furthermore, pre-treatment of cells with $10 \mu \mathrm{M}$ of SP600125, a specific JNK inhibitor, for $12 \mathrm{~h}$ blocked KML001induced phosphorylation of JNK, and subsequently abrogated the effect of KML001 on STAT1 and STAT3 (Fig. 4C).

Additionally, pre-treatment of HL-60 and HL-60R cells for $12 \mathrm{~h}$ with $20 \mu \mathrm{M}$ of SB202190, specific inhibitor of p38 protein, blocked KML001-induced p-p38, and subsequently abrogated the effect of KML001 on STAT1 (Fig. 4D). The examination of the effect of KML001 on PI3K/Akt signaling showed downregulation of p-mTOR, p-Akt and p-Raf proteins, while p-PTEN was upregulated in HL-60 and HL-60R cells (Fig. 5). In contrast, no alteration in expressions of the proteins was observed in $\mathrm{As}_{2} \mathrm{O}_{3}$-treated HL-60 and HL-60R cells.
Additional study showed that the expression of P65 and P50 subunits of NF- $\mathrm{kB}$ was decreased in KML001-treated HL-60 and HL-60R cells (Fig. 5). These results suggest that the anti-proliferative effect of KML001 might be mediated via various cell signaling including JAK/STAT, MAPK/ERK and PI3K/Akt pathways in HL-60 and HL-60R cells.

The effect of telomere length and hTERT in HL-60 and $H L-60 R$. The maintenance of telomere lengths is critical for chromosomal integrity in cells. It has been shown that KML001 targets the telomere (12). In this experiment, KML001 $\left(1 \times 10^{-7} \mathrm{M}\right)$ induced TRF length shortening in a time-dependent manner in HL-60 and HL-60R cells (Fig. 6A). In order to examine whether KML001 has an effect on the catalytic subunit of telomerase, hTERT, real-time PCR analysis with RNA extracted from KML001-treated HL-60 and HL-60R cells was done, showing that hTERT mRNA expression was inhibited in KML001-treated HL-60 and HL-60R cells in a time-dependent manner (Fig. 6B).

Induction of telomere-associated DNA damage by KMLOO1. Uncapping the telomere signal can induce cellular growth 

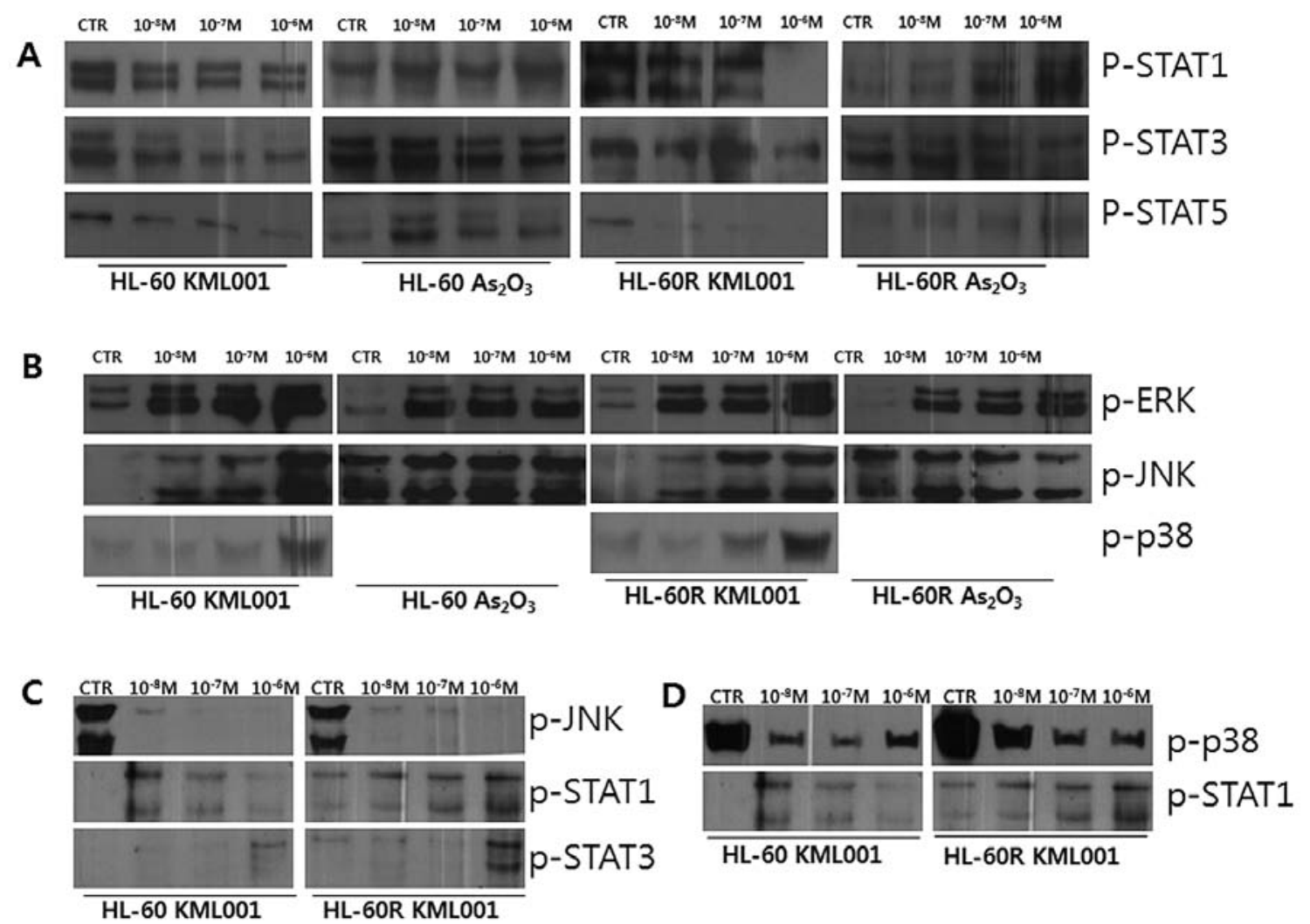

Figure 4. Effect of KML001 and $\mathrm{As}_{2} \mathrm{O}_{3}$ on cell signaling. (A) Modulation of STAT signaling in HL-60 and HL-60R cells. Cells were treated with KML001 or $\mathrm{As}_{2} \mathrm{O}_{3}$ for $2 \mathrm{~h}$ at indicated doses. (B) Modulation of MAPK signaling in HL-60 and HL-60R. Cells were treated with KML001 or As $\mathrm{O}_{3}$ for $2 \mathrm{~h}$ at indicated doses. (C) Blocking of JNK phosphorylation by SP600125, a specific JNK inhibitor in HL-60 and HL-60R cells. Cells were pre-treated with $10 \mu \mathrm{M}$ of SP600125 for $1 \mathrm{~h}$ and further cultured with KML001 for $2 \mathrm{~h}$ at the indicated doses. (D) Blocking of p38 by SB202190, specific inhibitor of p38 protein in HL-60 and HL-60R cells. Cells were pre-treated with $20 \mu \mathrm{M}$ of SB202190 for $1 \mathrm{~h}$ and further cultured with KML001 for $2 \mathrm{~h}$ at the indicated doses.

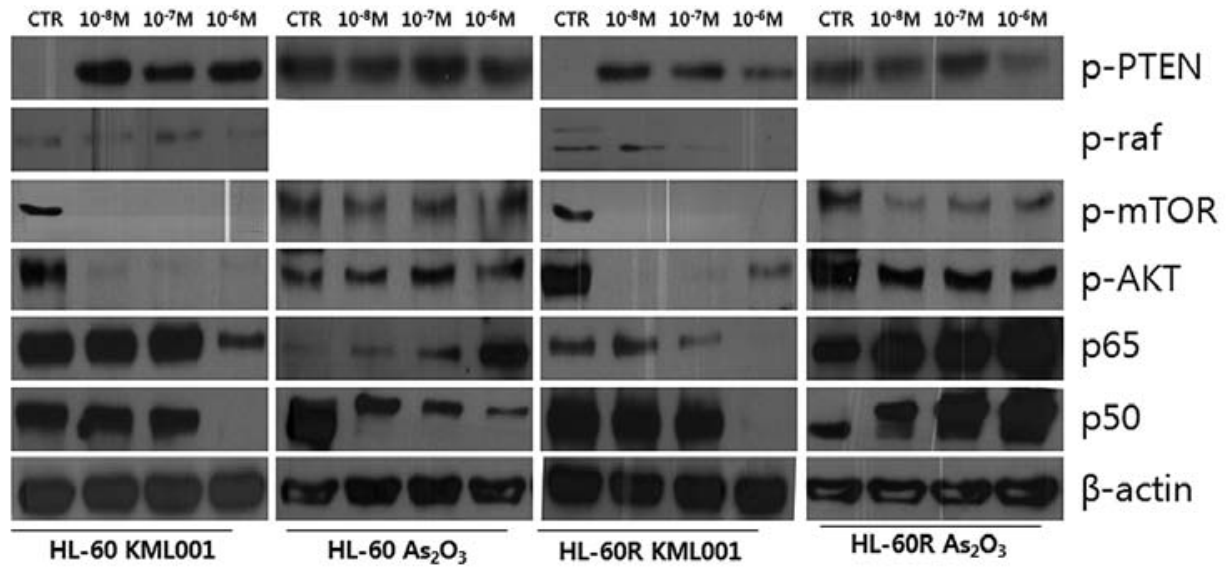

Figure 5. Modulation of PI3K/Akt signaling by KML001 and $\mathrm{As}_{2} \mathrm{O}_{3}$ in HL-60 and HL-60R cells. Cells were treated with $\mathrm{KML} 001$ or $\mathrm{As}_{2} \mathrm{O}_{3}$ for $2 \mathrm{~h}$ at indicated doses. Cells were lysed and proteins were separated by SDS-PAGE. Western blot analysis was performed using indicated antibodies.

arrest/apoptosis via telomere length shortening. It accelerates the double-strand break-mediated DNA damage signaling pathways, including phosphorylation of $\gamma-\mathrm{H}_{2} \mathrm{~A}_{\mathrm{X}}$ at Ser139, which represents an early event of DNA damage signaling $(12,19,20)$. Therefore, $\mathrm{p}-\gamma-\mathrm{H}_{2} \mathrm{~A}_{\mathrm{X}}$ has been known to be a marker for DNA damage checkpoint response in telomere-initiated senescence $(20,21)$. Accordingly, we examined whether KML001 treatment would induce the $\gamma-\mathrm{H}_{2} \mathrm{~A}_{\mathrm{X}}$ phosphorylation in HL-60 and HL-60R cells. Our ChIP assay demonstrated that $\mathrm{p}-\gamma-\mathrm{H}_{2} \mathrm{~A}_{\mathrm{X}}$ was upregulated in HL-60 and HL-60R cells at $24 \mathrm{~h}$ after treatment with $1 \times 10^{-7} \mathrm{M}$ of KML001, and their phosphorylated form of $\gamma-\mathrm{H}_{2} \mathrm{~A}_{\mathrm{X}}$ was maintained up to $48 \mathrm{~h}$ (Fig. 7).

\section{Discussion}

In the present study, we demonstrated for the first time that KML001 potently inhibited the proliferation of HL-60 and HL-60R cells by inducing cell cycle arrest and triggering 

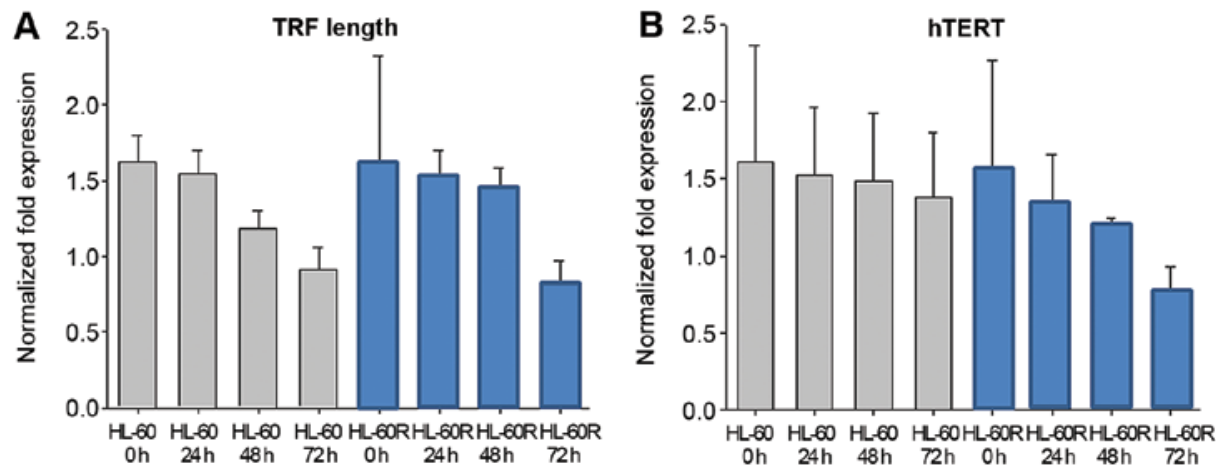

Figure 6. Effect of KML001 on telomere length and telomere gene expression. (A) Effect of KML001 on telomere length in HL-60 and HL-60R cells. Cells were treated with KML001 $\left(10^{-7} \mathrm{M}\right)$ for indicated times, and telomere length was calculated using Roche Diagnostics TeloTAGG telomere restriction fragment (TRF) length kit. The experiments were performed in triplicates. (B) Effect of KML001 on hTERT mRNA in HL-60 and HL-60R cells. Cells were treated with KML001 $\left(10^{-7} \mathrm{M}\right)$ for indicated times, and hTERT mRNA expression was measured by quantitative RT-PCR. The experiments were performed in triplicates.

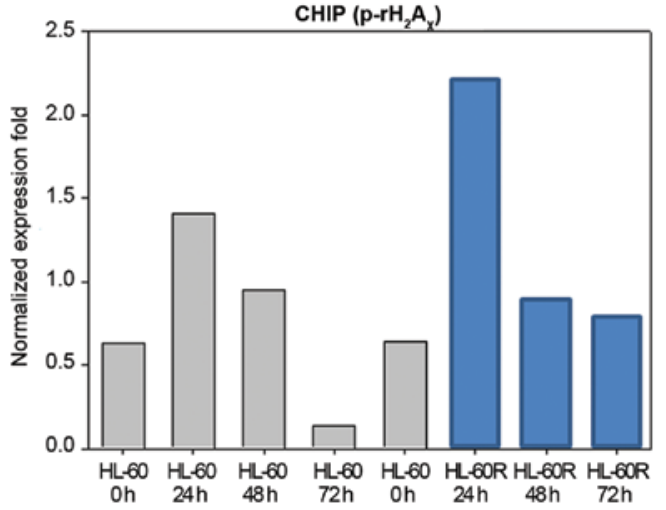

Figure 7. Effect of KML001 on telomere-associated DNA damage. The expression of $\mathrm{p}-\gamma-\mathrm{H}_{2} \mathrm{~A}_{\mathrm{X}}$, a marker for DNA damage checkpoint response in telomere-initiated senescence, was evaluated in HL-60 and HL-60R cells by chromatin immunoprecipitation (ChIP) assay. ChIP with $\gamma-\mathrm{H}_{2} \mathrm{~A}_{\mathrm{X}}$ revealed its very strong association with telomeres after KML001 treatment in HL-60 and HL-60R cells for $12 \mathrm{~h}$.

apoptosis. KML001 induced a dose-dependent inhibition of cellular proliferation of all AML cell lines including HL-60R cells as well as primary leukemic blasts from AML patients. The cell cycle analysis revealed that KML001 was able to prominently induce a G1 growth arrest of HL-60 and HL-60R cells at a concentration of $10^{-7} \mathrm{M}$ during 72-h exposure, in contrast, cell cycle arrest was not observed in $\mathrm{As}_{2} \mathrm{O}_{3}$-treated HL-60 and HL-60R cells. Among CDKs that regulate the cell cycle, CDK4 and CDK6 are activated in association with cyclin D during G1 progression, whereas CDK2 is activated primarily in association with cyclin $\mathrm{E}$ in the late $\mathrm{G} 1$ phase $(22,23)$. We found that the expression of CDK2, CDK4, and CDK6 was decreased in a time-dependent manner following treatment of KML001, and the expression of cyclin D1 and cyclin E was also decreased in HL-60 and HL-60R cells. These results suggested that KML001 affected the cell cycle arrest in HL-60 and HL-60R cells through changes in the cell cycle-regulatory proteins. It is known that a family of cyclindependent kinase inhibitors (CDKIs) plays a major role in the negative regulation of CDKs and is involved in the arrest of G1 cell cycle resulting in antiproliferative signals. In the present study, KML001 treatment showed a marked upregulation of
CDKI, p27 protein, in HL-60 and HL-60R cells. In addition, the accumulation of $\mathrm{p} 27$ protein in association with $\mathrm{G} 1$ arrest was detected largely in complexes with CDK2, CDK4 and CDK6. These increased formations of p27-CDK2, p27-CDK4 and p27-CDK6 complexes support the notion that KML001 may decrease CDK4-, CDK6- and CDK2-associated kinase activities in HL-60 and HL-60R cells. In fact, our kinase assay showed that KML001 reduced CDK2-, CDK4- and CDK6-associated kinase activities in HL-60 and HL-60R cells, in contrast, $\mathrm{As}_{2} \mathrm{O}_{3}$ did not. Taken together, the $\mathrm{G} 1$ arrest by KML001 might be mediated by downregulation of CDK2-, CDK4- and CDK6 kinase activities in association with induction of p27 in HL-60 and HL-60R cells.

Our data demonstrated that KML001 markedly induced the apoptosis in HL-60 and HL-60R cells, showing the downregulation of Bcl-2 and effector procaspase- 3 in a dosedependent manner in HL-60 and HL-60R cells, in contrast, $\mathrm{As}_{2} \mathrm{O}_{3}$ did not. We confirmed apoptosis using Annexin/PI double staining in which apoptotic cells were increased in a time-dependent manner in HL-60 and HL-60R cells.

Signal transduction pathways regulate cellular differentiation, division and cell death. Therefore, we investigated the effect of KML001 on the signal transduction pathways. STATs are latent cytoplasmic transcription factors activated by JAK which are constitutively associated with cytokines and growth factor receptors, and frequently activated in many types of human malignancies including leukemia $(24,25)$. Activated/phosphorylated STATs by external stimuli are dimerized and translocated to the nucleus where they bind to response elements on DNA, and activate the transcription of target genes, resulting in cellular survival, proliferation, differentiation and apoptosis (26-28). The present study showed that KML001 decreased p-STAT1, p-STAT3 and p-STAT5 in HL-60 and HL-60R cells in a dose-dependent manner. Thus, JAK/STAT pathways might be involved in KML001-induced apoptosis. Mitogen-activated protein kinase (MAPK) pathways contribute to control and determine the cell fate in response to many environmental stimuli. It has been suggested that ERK activation exerts a cytoprotective effect, whereas JNKs and p38-MAPKs seems to be involved in apoptosis $(29,30)$. However, the involvement of subfamilies of MAPK regarding the apoptosis depends on the cell type and stimulating 
agents (30). In the present study, KML001 increased levels of p-JNK as well as p-p38 protein. Furthermore, SP600125, a specific JNK inhibitor, blocked KML001-induced phosphorylation of JNK, and subsequently abrogated the effect of KML001 on STAT1 and STAT3 in HL-60 and HL-60R. Also, pre-treatment of HL-60 and HL-60R cells with SB202190, specific inhibitor of p38 protein, blocked KML001-induced p-p38, and subsequently abrogated the effect of KML001 on STAT1. The amount of phosphorylated ERK was increased by treatment of KML001. These results suggest that KML001induced apoptosis may be dependent upon or tightly regulated by activation of MAPK pathways.

Phosphatidylinositol 3-kinase (PI3K)/Akt pathway is crucial in signaling of diverse biological functions, including cell proliferation, survival and metastasis (31-33). PTEN, a tumor suppressor gene, downregulates the PI3K signal, thus, the loss of function of PTEN results in inappropriate signaling to downstream molecules, including Akt, Raf and mTOR (34-36). In the present study, the p-PTEN was upregulated, while p-Akt and p-Raf were downregulated in KML001-treated HL-60 and HL-60R cells. Taken together, these results suggest that induction of PTEN by KML001 may downregulate the intermediate molecules of PI3K/Akt pathway including Raf which deactivates MAPK signaling, or may directly inhibit MAPK signaling, thereby inhibiting cellular proliferation of HL-60 and HL-60R cells.

$\mathrm{NF}-\kappa \mathrm{B}$ is a heterodimer composed of the p65 and p50 subunits that contains the transcriptional activation domain required for initiation of gene transcription (37). Also, NF- $\mathrm{B}$ protein is known to be a positive regulator of cell cycle progression, and it activates target genes, such as cyclin D1, D2, D2 and $\mathrm{E}(38,39)$. In this study, the expression of $\mathrm{p} 65$ and p50 was decreased in the KML001-treated HL-60 and HL-60R cells, suggesting that KML001 may inhibit the activation of NF- $\mathrm{BB}$.

Arsenic has been found to target telomere by inhibition of the transcription of the human telomerase reverse transcriptase (hTERT) and alteration of telomere length, telomerase activity, and telomere binding proteins (40). We demonstrated that the telomere length (TRF) in HL-60 and HL-60R cells was shortened after treatment with KML001. In addition, realtime PCR with RNA extracted from KML001-treated HL-60 and HL-60R cells showed a reduction of catalytic subunit of telomerase, hTERT, in a time-dependent manner.

Uncapping the telomere signal can induce cellular growth arrest/apoptosis via telomere length shortening. It accelerates the double-strand break-mediated DNA damage signaling pathways, including $\mathrm{p}-\gamma-\mathrm{H}_{2} \mathrm{~A}_{\mathrm{X}}$ at Ser139, which represents an early event of DNA damage signaling (20). Therefore, $\mathrm{p}-\gamma-\mathrm{H}_{2} \mathrm{~A}_{\mathrm{X}}$ is known to be a marker for DNA damage checkpoint response in telomere-initiated senescence (21). Our telomere associated p- $\gamma-\mathrm{H}_{2} \mathrm{~A}_{\mathrm{X}} \mathrm{ChIP}$ assay showed that KML001 increased $\gamma-\mathrm{H}_{2} \mathrm{~A}_{\mathrm{X}}$ phosphorylaton in HL-60 and HL-60R cells, suggesting that KML001 might target the telomere.

In summary, KML001 inhibited the cellular proliferation of human primary leukemic blasts as well as AML cell lines including HL-60R via induction of the cell cycle arrest, triggering apoptosis and modulation of STATs, MAPK, PI3K and $\mathrm{NF}-\kappa \mathrm{B}$ signaling. In addition, KML001 targeted the telomere. Therefore, KML001 might be a candidate agent for the treatment of de novo as well as refractory AML patients.

\section{Acknowledgements}

The present study was conducted in the Hanyang University Hospital Clinical Laboratory, and it was supported in part by Dong-A Socio Holdings, Inc.

\section{References}

1. Waxman S and Anderson KC: History of the development of arsenic derivatives in cancer therapy. Oncologist 2 (Suppl 6): $3-10,2001$

2. Soignet SL, Maslak P, Wang ZG, Jhanwar S, Calleja E, Dardashti LJ, Corso D, DeBlasio A, Gabrilove J, Scheinberg DA, Pandolfi PP and Warrell RP: Complete remission after treatment of acute promyelocytic leukemia with arsenic trioxide. N Engl J Med 339: 1341-1348, 1998.

3. Soignet SL, Frankel SR, Douer D, Tallman MS, Kantarjian H, Calleja E, Stone RM, Kalaycio M, Scheinberg DA, Steinherz P, Sievers EL, Coutre S, Dahlberg S, Ellison R and Warrell RP: United States multicenter study of arsenic trioxide in relapsed acute promyelocytic leukemia. J Clin Oncol 19: 3852-3860, 2001.

4. Uslu R, Sanli UA, Sezgin C, Karabulut B, Terzioglu E, Omay SB and Goker E: Arsenic trioxide-mediated cytotoxicity and apoptosis in prostate and ovarian carcinoma cell lines. Clin Cancer Res 6: 4957-4964, 2000.

5. Zhang TC, Cao EH, Li JF, Ma W and Qin JF: Induction of apoptosis and inhibition of human gastric cancer MGC-803 cell growth by arsenic trioxide. Eur J Cancer 35: 1258-1263, 1999.

6. Ling YH, Jiang JD, Holland JF and Perez-Soler R: Arsenic trioxide produces polymerization of microtubules and mitotic arrest before apoptosis in human tumor cell lines. Mol Pharmacol 62: 529-538, 2002.

7. Miller WH, Schipper HM, Lee JS, Singer J and Waxman S: Mechanisms of action of arsenic trioxide. Cancer Res 62: 3893-3903, 2002

8. Chen GQ, Zhu J, Shi XG, Ni JH, Zhong HJ, Si GY, Jin XL, Tang W, Li XS, Xong SM, Shen ZX, Sun GL, Ma J, Zhang P, Zhang TD, Gazin C, Naoe T, Chen SJ, Wang ZY and Chen Z: In vitro studies on cellular and molecular mechanisms of arsenic trioxide $\left(\mathrm{As}_{2} \mathrm{O}_{3}\right)$ in the treatment of acute promyelocytic leukemia: $\mathrm{As}_{2} \mathrm{O}_{3}$ induces NB4 cell apoptosis with downregulation of Bcl-2 expression and modulation of PML-RAR alpha/ PML proteins. Blood 88: 1052-1061, 1996.

9. Hug N and Lingner J: Telomere length homeostasis. Chromosoma 115: 413-425, 2006

10. Chou WC, Hawkins AL, Barrett JF, Griffin CA and Dang CV: Arsenic inhibition of telomerase transcription leads to genetic instability. J Clin Invest 108: 1541-1547, 2001.

11. Litzow MR: Arsenic trioxide. Expert Opin Pharmacother 9: 1773-1785, 2008

12. Phatak P, Dai F, Butler M, Nandakumar MP, Gutierrez PL, Edelman MJ, Hendriks H and Burger AM: KML001 cytotoxic activity is associated with its binding to telomeric sequences and telomere erosion in prostate cancer cells. Clin Cancer Res 14: 4593-4602, 2008.

13. Glienke W, Chow KU, Bauer N and Bergmann L: Downregulation of wtl expression in leukemia cell lines as part of apoptotic effect in arsenic treatment using two compounds. Leuk Lymphoma 47: 1629-1638, 2006

14. Jin JO, Song MG, Kim YN, Park JI and Kwak JY: The mechanism of fucoidan-induced apoptosis in leukemic cells: involvement of ERK1/2, JNK, glutathione, and nitric oxide. Mol Carcinog 49: 771-782, 2010.

15. Yoon JS, Won YW, Kim SJ, Oh SJ, Kim ES, Kim BK, Cho CG, Choi JH, Park BB, Lee MH and Lee YY: Anti-leukemic effect of 2-pyrone derivatives via MAPK and PI3 kinase pathways. Invest New Drugs 30: 2284-2293, 2012.

16. Vermes I, Haanen C, Steffens-Nakken $\mathrm{H}$ and Reutelingsperger C: A novel assay for apoptosis. Flow cytometric detection of phosphatidylserine expression on early apoptotic cells using fluorescein labelled Annexin V. J Immunol Methods 184: 39-51, 1995.

17. d'Adda di Fagagna F, Hande MP, Tong WM, Roth D, Lansdorp PM, Wang ZQ and Jackson SP: Effects of DNA nonhomologous endjoining factors on telomere length and chromosomal stability in mammalian cells. Curr Biol 11: 1192-1196, 2001. 
18. Cawthon RM: Telomere length measurement by a novel monochrome multiplex quantitative PCR method. Nucleic Acids Res 37: e21, 2009.

19. Blackburn EH: Telomere states and cell fates. Nature 408: 53-56, 2000.

20. d'Adda di Fagagna F, Reaper PM, Clay-Farrace L, Fiegler H, Carr P, Von Zglinicki T, Saretzki G, Carter NP and Jackson SP: A DNA damage checkpoint response in telomere-initiated senescence. Nature 426: 194-198, 2003.

21. Phatak P, Cookson JC, Dai F, Smith V, Gartenhaus RB, Stevens MF and Burger AM: Telomere uncapping by the G-quadruplex ligand RHPS4 inhibits clonogenic tumour cell growth in vitro and in vivo consistent with a cancer stem cell targeting mechanism. Br J Cancer 96: 1223-1233, 2007.

22. Sherr CJ: Cancer cell cycles. Science 274: 1672-1677, 1996.

23. Dynlacht BD: Regulation of transcription by proteins that control the cell cycle. Nature 389: 149-152, 1997.

24. Darnell JE, Kerr IM and Stark GR: Jak-STAT pathways and transcriptional activation in response to IFNs and other extracellular signaling proteins. Science 264: 1415-1421, 1994.

25. Bowman T, Garcia R, Turkson J and Jove R: STATs in oncogenesis. Oncogene 19: 2474-2488, 2000.

26. Akira S: Functional roles of STAT family proteins: lessons from knockout mice. Stem Cells 17: 138-146, 1999

27. Hirano T, Ishihara K and Hibi M: Roles of STAT3 in mediating the cell growth, differentiation and survival signals relayed through the IL-6 family of cytokine receptors. Oncogene 19: 2548-2556, 2000.

28. Smithgall TE, Briggs SD, Schreiner S, Lerner EC, Cheng H and Wilson MB: Control of myeloid differentiation and survival by Stats. Oncogene 19: 2612-2618, 2000.

29. Cross TG, Scheel-Toellner D, Henriquez NV, Deacon E, Salmon M and Lord JM: Serine/threonine protein kinases and apoptosis. Exp Cell Res 256: 34-41, 2000.
30. Wada T and Penninger JM: Mitogen-activated protein kinases in apoptosis regulation. Oncogene 23: 2838-2849, 2004.

31. Willems L, Tamburini J, Chapuis N, Lacombe C, Mayeux P and Bouscary D: PI3K and mTOR signaling pathways in cancer: new data on targeted therapies. Curr Oncol Rep 14: 129-138, 2012.

32. Cantley LC: The phosphoinositide 3-kinase pathway. Science 296: 1655-1657, 2002.

33. Hidalgo $\mathrm{M}$ and Rowinsky EK: The rapamycin-sensitive signal transduction pathway as a target for cancer therapy. Oncogene 19: 6680-6686, 2000 .

34. Ortega-Molina A and Serrano M: PTEN in cancer, metabolism, and aging. Trends Endocrinol Metab 24: 184-189, 2013.

35. Sawyers CL: Rational therapeutic intervention in cancer: kinases as drug targets. Curr Opin Genet Dev 12: 111-115, 2002.

36. Janus A, Linke A, Cebula B, Robak T and Smolewski P: Rapamycin, the mTOR kinase inhibitor, sensitizes acute myeloid leukemia cells, HL-60 cells, to the cytotoxic effect of arabinozide cytarabine. Anticancer Drugs 20: 693-701, 2009.

37. Baldwin AS: The NF-kappa B and I kappa B proteins: new discoveries and insights. Annu Rev Immunol 14: 649-683, 1996.

38. Guttridge DC, Albanese C, Reuther JY, Pestell RG and Baldwin AS: NF-kappaB controls cell growth and differentiation through transcriptional regulation of cyclin D1. Mol Cell Biol 19: 5785-5799, 1999 .

39. Hinz M, Krappmann D, Eichten A, Heder A, Scheidereit C and Strauss M: NF-kappaB function in growth control: regulation of cyclin D1 expression and G0/G1-to-S-phase transition. Mol Cell Biol 19: 2690-2698, 1999

40. Zhang Y, Cao EH and Qin JF: Up-regulation of telomere-binding TRF1, TRF2 related to reactive oxygen species induced by $\mathrm{As}_{2} \mathrm{O}$ in MGC-803 cells. Eur J Pharmacol 516: 1-9, 2005. 